\title{
PJIEE
}

\section{ACTION RESEARCH ON USING SHORT STORIES TO BOOST EFL LEARNERS' PERFORMANCE: A SYSTEMATIC REVIEW}

\author{
by \\ Parlindungan Pardede \\ Universitas Kristen Indonesia \\ parlpard2010@gmail.com
}

Received: March 14, 2021,

Reviewed1: September 15, 2021, Accepted: September 24, 2021, reviewer: June 20, 2021

reviewed2:September 19,2021

published: October 4, 2021

\begin{abstract}
:
Various conceptual and empirical research has revealed that short stories are effective learning tools teachers can use to boost English as a foreign language (EFL) learning performances. However, most EFL teachers are still find using short stories in EFL classrooms challenging. To solve the problem, conducting action research on using short stories in EFL teaching seems to be the best option. This study aims at reviewing action research on using short story use to increase EFL students' learning achievement. Employing four inclusion and three exclusion criteria, 12 action research articles indexed in Google Scholar and published in 2011-2020 were selected. Data were analysed using the constant comparative method. The results showed that the use of short stories employing the Before-DuringAfter reading strategy, language-based model, and literature as content model managed to attain the intended outcomes in 2 to 3 cycles. This review is ended by highlighting some research gaps for future action research and future review as well.
\end{abstract}

Keywords: action research, EFL, short story

\section{INTRODUCTION}

There is a strong belief that the essence of today's English as a Foreign Language (EFL) learning and teaching is not only to facilitate students to master English language skills and components but also to empower them to use the target language in socially and culturally proper ways. This view has recently made literary works play critical roles in EFL classrooms as they are considered as advantageous authentic learning material, facilitate language development, offer cultural enrichment, and boost personal involvement (Collie \& Slater, 1991). Additionally, literary works are also a powerful educational tool as they can create more interesting, enjoyable, and encouraging learning (Ghosn, 2002; Savvidow, 2004), advance critical thinking, and proliferate aesthetic appreciation (Ghosn, 2002; Parkinson \& ReidThomas, 2000).

Literature use as a source and tool for language learning has been changing for over three centuries. When modern language teaching started in the 18th century, literature was included 
in the curriculum. It was also incorporated in English teaching in Britain and its colonies since the 19th century (Hall, 2005). When foreign language teaching began to flourish in the 19th century, literature was also employed as one of the major teaching materials and tools. Dominated by the Grammar Translation Method up to the beginning of the 20th century, reading and translating literary texts from the target language to the learners' mother tongue became one of the main learning activities in foreign language classrooms. Kramsch and Kramsch (2002) even claimed that foreign language learning in that era was inevitably the study of literature. Yet, when the Direct Method replaced the Grammar Translation Method at the beginning of the 20th century, literature use in foreign language learning began to decline. It was even completely removed when the Direct Method was replaced by language teaching approaches focusing on spoken language acquisition (Audiolingualism, Suggestopedia, the Silent Way, Total Physical Response, and the Natural Approach). But literature found its way back to language classrooms in the 1980s with the rise of the Communicative Language Teaching approach. The need for authentic texts as teaching materials to support communicative teaching had opened the gateway for literature to be included in language curriculum again. Since then, the number of publications and research acknowledging the various benefits of using literature in language classrooms keeps on increasing.

Compared to other literary genres, short stories are often considered the most effective literary works to use in EFL learning and teaching because, besides sharing the potentials of other literary genres to elevate students' performance in language learning, short stories have three unique characteristics and various pedagogical advantages (Pardede, 2021). The unique characteristics include their brevity, practicality, and convenience. Short stories' brevity emerges from the fact that, unlike a novel that obliges a long time to read out and discuss, a short story focuses only on a theme, covers only a plot, and includes a limited number of characters. This makes it possible for students to deal with a short story in one or two class sessions. The practicality of short stories is caused by the fact that, unlike poetry which commonly contains various figurative languages and connotative words, short stories predominantly use daily languages. This enables students to read them independently or with minimum guidance from the teachers. Finally, different from drama that requires much preparation to act out, short stories are convenient to use. Its use needs texts only.

Short stories are not only brief, practical, and convenient but also motivating (Vural, 2013) as they are generally about human experiences in ordinary lives that students find relatively easy to familiarize with. Additionally, since they cover numerous topics, themes, and 
styles, they provide teachers an ample opportunity to choose works that meet their students' interests, needs, and tastes. Additionally, since they were written for native speakers, short stories offer authentic examples of language components uses in contexts and provide cultural loads that increase students' cultural awareness. These make them very potential to use as motivating sources for facilitating students to practice and fuse language skills and components, to convey information and ideas, to cultivate values and beliefs, or even to transmit subliminal messages (King, 2001). Arigol (2001, as cited in (Hişmanoğlu, 2005) listed various pedagogical advantages of short stories over other literary genres, i.e., short stories: make students' reading task easier, diminish anxiety, enable students to have a better view of other people and other cultures, provide a fictional and fascinating world, hone creativity and critical thinking skills; and increase cultural awareness. (Pathan, 2013) accentuated that using short-stories in EFL classrooms is advantageous because they facilitate students' linguistic, socio-cultural, personal, and emotional development.

Various experimental research has confirmed the effectiveness of short story uses in EFL classrooms. Some of them revealed that the use of short stories improved reading (Vural, 2013; Saka, 2014), listening (Tamjid \& Hassanzadeh, 2012), speaking (Omidi \& Zafarghandi, 2016; Nur Iman, 2017), and writing (Bartan, 2017; Pradana, 2015). Some others research showed that short stories can be effectively used for vocabulary building (Ahmed, 2017), pronunciation improvement (Laadi et al., 2014), grammar learning (Şentürk \& Kahraman, 2017), memory enhancement (Ghazanfari et al., 2014), critical thinking development (Khatib \& Mehrgan, 2012), and cultural awareness advancement (Nasirahmadi et al., 2014).

There is no exact formula for the effective use of short stories in EFL classrooms. However, as general guidelines, short stories can be exploited to facilitate language learning by applying BDA reading strategy, language-based model, literature as content model, and literature as personal enrichment model. BDA reading strategy consists of three stages: before (pre-) reading, during (while-) reading, and after (post-) reading. Before reading stage is intended to motivate and provide background information that will help students understand the story. Various activities could be selected and adapted to meet the students' language proficiency level and the learning objective, like discussing the meaning of the story's title and the main character, discussing glossary, brainstorming information relevant to the story or its author, and searching the geographical or historical background. The during-reading stage begins with silent reading and proceeds with intensive reading activities, such as guessing the meaning of unfamiliar words in context, textual analysis, predicting what will happen next, 
describing a character, determining the conflict, and so on. To make this stage more effective, teachers can ask the students to conduct the activities interactively. Activities in the after reading stage, depending on the students' language proficiency level, are intended to enable the student to summarize, relate the story with their life, respond to the story orally or in written form, discuss the theme and characters, identify, and analyze the grammatical structures, transform some dialogs to be a descriptive paragraph or vice-versa, act out some parts of the story, and so on. Figure 1 illustrates the three stages of the BDA reading strategy with some common activities for each stage. The activities lists are far from being complete. Many more relevant items can be added to each.

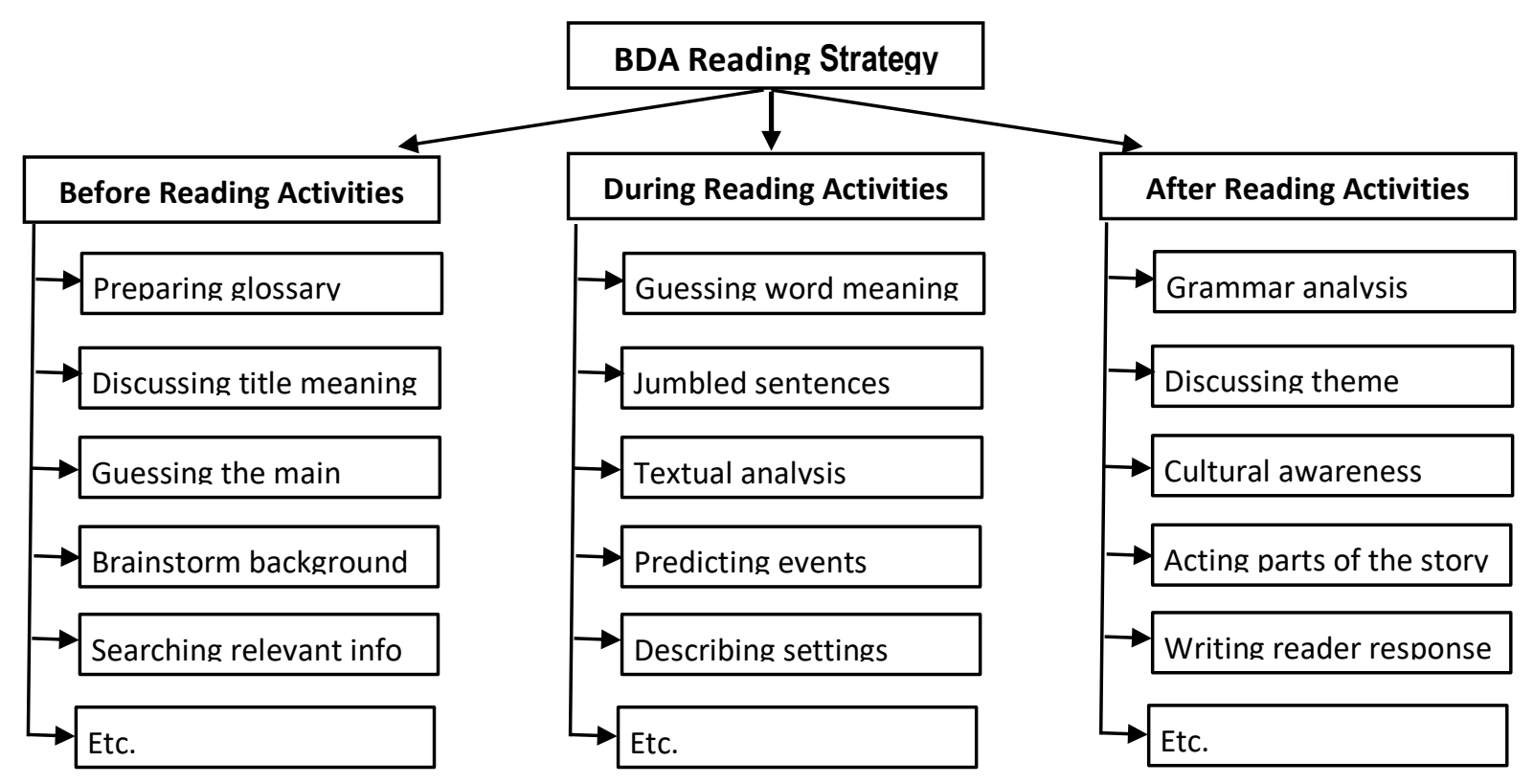

Figure 1: BDA Reading Strategy for Using Short Stories

In each stage, teachers can select, adapt, and combine various activities to meet the students' interest, language proficiency level, and preference and to achieve the intended outcomes as well. If the objective is to improve students' listening skills, each stage will consequently be dominated by activities related to the use of the audio/video recorded version of the story. If the objective is to promote students' critical thinking skills, the predominant activities are, for instances, comprehending literal or implied meanings, determining the narrator's tone, searching for events and actions causal relationship, analyzing the integrity of characters' statement and action, considering the correlation of the theme and points of views, 
and relating what students have learned to the real-life or other fields. These activities provide opportunities for students to reflect, infer, analyze, and synthesize the presented information.

The language-based model, literature as content model, and literature as personal enrichment model are three approaches suggested by Lazar (1993). The language-based approach is suitable for facilitating learning that focuses on the language components available in the short stories, including vocabulary, grammar, and pronunciation. The literature as a content approach is implemented by suiting the content and style of the short stories with students' needs or the learning objectives. Short stories containing extensive dialogs, for instance, are suitable to facilitate speaking skills development, short stories containing many cultural contents are proper for activities intended to promote cultural awareness, and the audio recorded version of short stories are used to develop speaking skills. The third model, literature for personal enrichment, is suitable to facilitate an ample opportunity for students to enlarge students' knowledge and experiences regarding particular genres of short stories. Students who like adventure fiction could be assigned short adventure stories. Lazar (1993) accentuated that each of the approaches could be administered independently or they can be integrated following the learning objectives.

Although short stories offer various advantages to facilitate EFL learning and teaching, many EFL teachers are still unenthusiastic to use them in their classrooms. According to some studies (Ganakumaran et al., 2003; Khatib \& Nourzadeh, 2011; Lima, 2010), this is due to teachers' lack of clear objectives regarding the role of literature, inadequate competence to integrate literature into the classrooms, insufficient background knowledge and preparation in literature, and unattainability of pedagogically-well-designed materials. In short, their knowledge and skills inadequacy and ready-to-use pedagogical materials scarcity make many teachers feel reluctant to use short stories in their classrooms.

In the field of education, one of the best ways to overcome teachers' inappropriate clarity and understanding of a problem or issue and their inadequate competence to adopt new teaching methods, materials, and tools is action research. Defined by Mills (2007) as "any systematic inquiry conducted by teacher researchers, principals, school counselors, or other stakeholders in the teaching/learning environment to gather information about how their particular schools operate, how they teach, and how well their students learn" (p. 5), action research is a powerful tool which enables teachers not only to advance their teaching practices but also acquire more understanding about their students, colleagues, and themselves which, in turn, will support their effort to continually improve (Ferrance, 2000). As a research design, it also empowers teachers 
to be researchers who can inquire to improve their instruction and thus increase their students 'learning outcomes. Since it usually deals with small-scale, contextualized, and localized focuses, and aims at discovering, monitoring, or developing changes to practice (Wallace, 2000), action research is considered very suitable for teachers.

Cohen et al. (2007) posited that action research can be implemented in almost every setting where a problem involving people, procedures, and tasks requires a solution, or where some changes are needed to achieve a more desirable result. Educational action research, therefore, could be employed to solve problems related to cognitive, psychomotor, and attitude domains. It could be effectively used in the attempt to adopt new teaching methods, learning strategies, materials, and media. In terms of the psychomotor domain, it can be employed to develop skills involving motor muscles. In terms of the attitudinal domain, action research could be used to encourage students to embrace more positive attitudes to learning or to facilitate teachers' continuing professional development. Thus, in the EFL context, action research can be employed to increase students' performances in terms of language skills, pronunciation, vocabulary, and grammar acquisition using short stories. It can also be administered to promote students' learning motivation, communicative competence, critical thinking skills, and cultural awareness by using short stories.

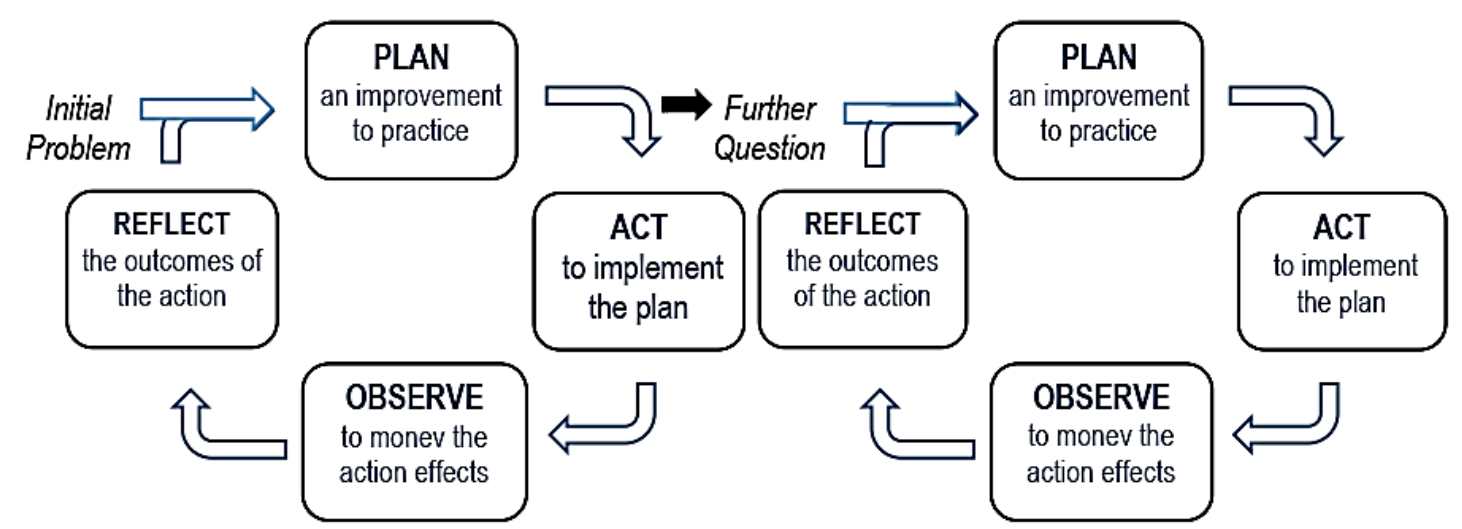

Figure 2. Action research moving forward (COBE, 2005)

Action research may be conducted individually, in pairs, in groups, or across wider organizational clusters. When some teachers conduct the same action research in some classrooms of the same level, they can have various benefits, including planning new interventions, collaborate at some stages, exchange and discuss ideas, compare findings, and set up communities of practice (Burns, 1999). The analysis, action, and reflection in action research are conducted through a spiral of an iterative or cyclical process. A cycle consists of 
four major phases: plan, act, observe and reflect (Figure 2). The process begins by planning activities in which teachers (and possibly students) determine the problem to solve, verify why it occurs, and decide what action or intervention can be employed to solve it (Plan). Being sure of the solution to take, teachers devise a plan to implement an action/intervention, observe and record the action. After that, the plan is implemented (Act) and related observations are documented (Observe). During the implementation of the action, one or more of the teacherresearcher conduct the actions, and one or more other researchers (collaborator) observe and record it. The obtained data are then critically analyzed and discussed so that they make sense to the researchers (Reflect).

The intended improvement is rarely achieved in one cycle. That's why action research principally needs more than one cycle. As the cycles are repeated, more stakeholders' participation is obtained, and it will stimulate a better understanding of how to attain the targets (Crane \& Rihardson, 2000). Unlike the plan in the first cycle, however, the plans for the second cycle are devised based on what has been learned through the first cycle because the problem to resolve through the actions/interventions of the second cycle is the one identified through the first cycle reflection stage. If the intended improvement is achieved at the end of the second cycle, the action research is terminated, but if it is not yet achieved, a plan for the third cycle should be devised based on what is learned through the reflection stage of the second cycle. To see detailed steps of action research, see the framework developed by Mills (2007) and Pardede (2019). Both divide each of the four stages into specific operational steps.

This review aims at exploring what action research published in 2011-2020 reveals about the use of short stories in EFL classrooms. Some systematic reviews on action research carried out in EFL contexts have been undertaken. Ali (2020) reviewed 40 action research articles published in 2010-2019 on the integration of technological tools and visual aids to develop language skills in ESL/EFL contexts. Vaughan \& Burnaford's (2016) review concentrated on the goals, problems, policy, and implications of 276 action research dissertations in graduate teacher education programs published from 2000 to 2014. However, action research focusing on the use of short stories in EFL classrooms has never been reviewed. To fill in the gap, this review attempted to examine the action research exploring short stories use in EFL classrooms published in 2011-2020. This review focuses on the objectives, process, and results of the selected studies. The results will hopefully advance knowledge and skills in using short stories to increase EFL learning effectiveness and improve EFL students' learning achievement. Accordingly, this review will address the following questions. 
1. What were the objectives of the reviewed action research on short story use in EFL classrooms published in 2011-2020?

2. What are the educational levels of participants involved in the reviewed studies?

3. What interventions did the reviewed research implement?

4. What are the results of the action research?

5. What gaps are there in the reviewed action research that should be addressed by future research?

\section{METHOD}

\section{Design}

This study was carried out employing the systematic literature method which is defined as a method for identifying, evaluating, and interpreting all findings on a research topic for finding the answer research questions that have been previously determined (Kitchenham \& Charters, 2007). It was conducted using the procedure proposed by Littell et al. (2008) consisting of five phases: the formulation of the problem, sampling, data collection, data analysis, and interpretation and the presentation of the result. The problem formulation was conducted by taking the needs of EFL teachers and researchers, to whom the results of this review might be useful, into consideration.

\section{Literature Search}

The literature search was conducted on 4-6 February 2021 by scanning the term "action research, using short story in EFL learning” in Google Scholar. Google Scholar was selected as the database selected as the source to identify the primary research to review based on two reasons. First, Google Scholar could provide massive searching results because it covers about 389 million documents (Gusenbauer, 2019). Second, it provides easy access to search and retrieve research articles and other scholarly literature from academic publishers and institutional repositories. The search provided 39 research articles which were selected using four inclusion criteria, i.e.: the research articles were written using the standard structure of research articles and published in academic journals, proceedings, or academic repositories; they report action research focusing on the use of short stories in EFL learning and teaching; they involved EFL students as participants; and they were published from 2011 to 2020. Using these criteria to screen the available articles, 20 potential research were obtained. Then, they were screened again to decline the unqualified studies using the three exclusion criteria, i.e.: 
action research employing only one cycle; action research conducted in ESL contexts; and unpublished thesis or dissertation. After the second screening, 12 articles were remained to be reviewed. The model of citing is "offline automatic system by using Mendeley Desktop" (Turmudi, 2020, p. 59).

\section{Data Analysis}

Data were analyzed employing the constant comparative method. It was applied in four steps: (1) examining the first selected research; (2) noting its content to create a tentative theme; (3) evaluating the second article; and (4) comparing it to the theme of the first article. If these articles' theme is similar, the third article was examined. If the theme of the first and second articles was discovered different, another theme was generated. The review then continued by analyzing the next article and comparing it to the previous ones. Thus, every article was examined and compared to another.

\section{RESULT AND DISCUSSION}

\section{Results}

\section{Research Objectives}

RQ1: What were the objectives of the reviewed action research?

Table 1. The Objectives of the Reviewed Action Research

\begin{tabular}{llcc}
\hline No & Purpose & Number & Percentage \\
\hline 1 & To improve students' reading performance & 5 & $42 \%$ \\
\hline 2 & To improve students' listening skills & 1 & $8 \%$ \\
\hline 3 & To develop students' writing skills & 1 & $8 \%$ \\
\hline 4 & To enlarge students' vocabulary & 4 & $34 \%$ \\
\hline 5 & To enhance students' learning motivation & 1 & $8 \%$ \\
\hline \multicolumn{2}{c}{ Total } & 12 & $100 \%$ \\
\hline
\end{tabular}

As shown in Table 1, the greatest number (58\%) of the research focused on using short stories to enhance students' language skills, among which reading was the most frequently studied (dealt by 5 or $42 \%$ of the studies), followed by listening ( 1 study) and writing ( 1 study). Thus, none of the research focused on speaking skills development. Among the other studies, $4(34 \%)$ focused on using short stories to enlarge students' vocabulary, and 1 (8\%) employed short stories to enhance students' learning motivation. Thus, the action research on short story use in EFL classrooms published between 2011 and 2020 was predominantly conducted to increase students' reading comprehension performance and vocabulary building. The number 
of studies dealing with other language skills (listening and writing) was meager. Speaking skills and other language components (pronunciation and grammar) were not even included in the studies.

Such finding might give the impression that short stories are effective only to improve students' reading comprehension performance and vocabulary enrichment but ineffective to develop other language skills and language components acquisition. Yet, various experimental research has revealed that short stories can be effectively used to improve listening (Tamjid \& Hassanzadeh, 2012), speaking (Iman, 2017; Omidi \& Zafarghandi, 2016), writing (Bartan, 2017; Pradana, 2015), pronunciation (Laadi et al., 2014), and grammar acquisition (Şentürk \& Kahraman, 2017). Many authors (e.g., Collie \& Slater, 1991; Mourao, 2009; Murdoch, 2002; Pathan, 2013; Saka, 2014) also claimed short stories to be effective materials and tools to develop the four language skills, help language components acquisition, promote learning motivation and higher-level thinking skills, and inculcate values and morality. What is more, action research can be employed to solve problems related to cognitive, motoric, and attitude domains.

Since action research can be administered to increase EFL students' performances in all language skills and language components, to promote learning motivation, communicative competence, critical thinking skills, and to inculcate cultural awareness, the domination of reading and vocabulary development as the focus of the action research on short stories use in EFL classrooms published between 2011 and 2020 might be due to two major factors. First, the number of studies published from 2011 to 2020 was very limited. Second, the situations of the researchers' classes that drove them to prioritize or prefer to explore their students' reading and vocabulary development using short stories. That domination was not due to the ineffectiveness of both short stories and action research as tools for developing other areas of EFL learning and teaching besides reading comprehension and vocabulary development.

\section{Participants' Educational Levels}

RQ2: What are the educational levels of participants involved in the reviewed studies?

Table 2 shows that the greatest number $(67 \%)$ of the reviewed research involved secondary school students, followed by undergraduate students (40\%), and young learners (9\%). None of the research involved primary school pupils. This finding shows that the action research administering short stories in EFL classrooms published between 2011 and 2020 was 
predominantly conducted in secondary school levels. Fewer studies involved participants in lower educational levels (primary school and kindergarten).

Table 2. Participants' Educational Levels

\begin{tabular}{llcc}
\hline \multirow{2}{*}{ No } & \multirow{2}{*}{ Educational Level } & \multicolumn{2}{c}{ Number of Research } \\
\cline { 3 - 4 } & & f & $\%$ \\
\hline 1 & Undergraduate & 3 & 25 \\
\hline 2 & Secondary School & 8 & 67 \\
\hline 3 & Primary School & 0 & 0 \\
\hline 4 & Young Learners (Pre-Schoolers) & 1 & 8 \\
\hline \multicolumn{2}{c}{ Total } & 12 & 100 \\
\hline
\end{tabular}

This finding indicates there is an urgent need to conduct more action research involving students in lower educational levels. Since short stories, as far as they are appropriately selected to meet the students' interest, needs, and language proficiency levels, are claimed to be effective to use with primary, intermediate, or advanced students (e.g., Hişmanoğlu, 2005; Mourao, 2009), it is necessary to conduct more and more action research in all educational levels to provide us more empirical data concerning that claim.

\section{Action Research Interventions}

\section{RQ3: What interventions did the reviewed research implement?}

A majority (75\%) of the reviewed research applied the BDA Reading Strategy in the interventions, $17 \%$ implemented the language-based model, and $8 \%$ implemented the literature as the content model (Handayani, 2013). The BDA Reading Strategy, however, was administered with a variety of adaptations to suit the interventions with the learning objective and students' proficiency level. Almost a half (42\%) of the research applied it without too many adaptations. Other research adapted it by focusing on the use of active/interactive reading practice using guiding questions or reading journal writing in the during-reading stage (Dania, 2020; Ismail et al., 2019; Sarifah \& Suhartini, 2019), and concentrating on folk-tale-based learning activities use (Mantra \& Kumara, 2018). The language-based model was implemented by (Guritno, 2017) by combining intensive and extensive reading and (Mantra, 2017) by administering folktales-based learning activities to develop writing skills. The only study implementing the literature as a content model is (Handayani, 2013), in which most activities were focused on listening development by employing recorded short stories.

This finding denotes that due to its flexibility, the BDA Reading Strategy could be creatively adapted to use short stories in EFL classrooms to achieve various targets. The only 
thing teachers should pay attention to is to carefully select proper learning activities to meet the students' language proficiency level, interest, preference, and learning objective.

\section{Research Results}

RQ4: What are the results of the action research?

Table 3 shows that $76 \%$ of the reviewed research used test mean score $(\bar{X})$ to measure the outcome attainment, whereas $24 \%$ administered the number of participants that achieved the success indicator. The success indicator was set variously one from another, depending on the minimum passing standard (MPS) in the school where the action research was conducted. Table 3 shows that $75 \%$ of the reviewed research managed to pass the success indicator after implementing their treatments in 2 cycles, and the other $25 \%$ achieved the intended outcomes after 3 cycles. The cycles included various sessions. Almost a half (42\%) of the research had 4 sessions (meetings) per cycle, $17 \%$ had 3 sessions per meeting, $8 \%$ had 8 sessions, $8 \%$ had 5 sessions, whereas the rest $25 \%$ did not inform the session number in each cycle. Thus, on average, the action research included 4.3 sessions per cycle.

Since the research was aimed at using short stories to improve students' reading performance, listening, writing, vocabulary, and learning motivation and they managed to achieve the intended outcomes, it can be concluded that short stories can be effectively used to develop students' reading comprehension performance, listening, writing, vocabulary, and learning motivation. These findings approve the claim that short stories use can enhance students' language skills and language components (Collie \& Slater, 1991) and learning interest and motivation (Ghosn, 2002; Savvidow, 2004).

Table 3. The Baseline, Success Indicator, Result, and Number of Cycles

\begin{tabular}{|c|c|c|c|c|c|}
\hline \multirow{2}{*}{ No } & \multirow{2}{*}{ Study } & \multicolumn{3}{|c|}{ Measurements } & \multirow{2}{*}{$\begin{array}{c}\text { Number of } \\
\text { Cycle }\end{array}$} \\
\hline & & Baseline & Success Indicator & Result & \\
\hline 1 & Siahaan (2012) & $\bar{X}$ Pre- $T=42$ & MPS: 80 & $\overline{\mathrm{X}} \mathrm{PT}=92$ & 3 \\
\hline 2 & Handayani (2013). & $\overline{\mathrm{X}}$ Pre- $\mathrm{T}=61.2$ & MPS: 75 & $\overline{\mathrm{X}} \mathrm{PT}=76.28$ & 3 \\
\hline 3 & Handayani (2015) & (not informed) & $\begin{array}{l}\geq 75 \% \text { obtain MPS: } \\
70\end{array}$ & $88.24 \%$ & 2 \\
\hline 4 & Saripah \& Syukri (2017) & (not informed) & $\begin{array}{l}\geq 75 \% \text { obtain High } \\
\text { Motivation }\end{array}$ & $84 \%$ & 2 \\
\hline 5 & Guritno (2017) & $\overline{\mathrm{X}}$ Pre- $\mathrm{T}=56.2$ & MPS: 70 & $\overline{\mathrm{X}} \mathrm{PT}=73.41$ & 3 \\
\hline 6 & Mantra (2017) & $\bar{X}$ Pre- $T=36.6$ & MPS: 70 & $\overline{\mathrm{X}} \mathrm{PT}=74.4$ & 2 \\
\hline 7 & Mantra \& Kumara (2018). & $\overline{\mathrm{X}}$ Pre-T$=46$ & MPS: 75 & $\overline{\mathrm{X}} \mathrm{PT}=84$ & 2 \\
\hline 8 & Syafi (2018) & $\overline{\mathrm{X}}$ Pre- $\mathrm{T}=51.1$ & MPS: 60 & $\overline{\mathrm{X}} \mathrm{PT}=78.7$ & 2 \\
\hline 9 & Mustafa (2018) & (not informed) & MPS: 75 & $\overline{\mathrm{X}} \mathrm{PT}=87$ & 2 \\
\hline 10 & Dania (2019) & (not informed) & $\begin{array}{l}\geq 50 \% \text { enjoyed } \\
\text { reading very much }\end{array}$ & $54 \%$ & 2 \\
\hline
\end{tabular}




\begin{tabular}{llllll}
\hline 11 & Ismail, et al (2019). & $\overline{\text { X Pre-T }=55.7}$ & MPS: 70 & X PT $=82.21$ & 2 \\
\hline 12 & Male \& Sihite, (2019) & $\overline{\text { X Pre-T }=55.2}$ & MPS: 75 & X PT $=88.88$ & 2 \\
\hline
\end{tabular}

The finding that the reviewed research was conducted only in 2 to 3 cycles with 4.3 sessions per cycle to achieve the intended outcomes reveals that combining short story and action research to improve students' learning achievement in EFL classrooms can provide outstanding results. In this context, conducting action research to facilitate students learning in EFL classrooms is like combining two powerful tools to attain an objective. Both short stories and action research have been proven effective when they were employed separately in EFL classrooms. Short stories are effective to increase learning motivation cultivate reading interest (Saka, 2014), and facilitate students' linguistic, socio-cultural, personal, and emotional development (Pathan, 2013). Action research was effective to help students develop their reading, writing, listening, speaking, and pronunciation skills(Ali, 2020). When both of the powerful tools are combined to facilitate students learning in EFL classrooms, the intended outcomes could be achieved more effectively.

\section{Research Gaps}

RQ5: What gaps are there in the reviewed action research that should be addressed by future research?

As described earlier, the reviewed research focused only on 5 objectives, i.e., using short stories to develop three language skills (reading, listening, writing), one language area (vocabulary), and one attitudinal domain (learning motivation). The 5 objectives were not studied by an equal number of studies. The majority focused only on reading and vocabulary development. Studies inquiring the other three objectives were very meager. What is more, no study explored the development of speaking skills, pronunciation skills, grammar, cultural awareness, and critical thinking skills. Thus, future studies are needed to concentrate on using short stories to develop these EFL learning areas.

Secondly, the vast majority of the reviewed studies involved only secondary school and undergraduate students. Therefore, future studies are recommended to involve young learners and primary school students.

The third gap concerns the types of action research conducted. All of the reviewed studies were conducted in single classrooms. Although some of them employed collaborators, they were assigned merely as observers. Thus, they belong to individual action research only. Future 
studies need to be conducted in groups or across wider organizational clusters so that the teachers can collaborate in conducting actions, exchange and discuss ideas, compare findings, and set up communities of practice.

\section{CONCLUSION AND SUGGESTION}

The results and discussions above showed that the majority of the reviewed studies explored the use of short stories to develop students' reading comprehension and vocabulary. A little number of studies focused on using short stories to increase listening, writing, and learning motivation. Most of the studies administered the BDA Reading Strategy whose learning activities were adapted to the class conditions and the objective of the studies, while the rest employed t language-based model and literature as a content model. Since all studies managed to attain or pass the success criteria in 2 to 3 cycles, it was concluded that the combination of short stories and action research in EFL classrooms can provide outstanding results.

The review is restricted to action research articles specifically focused on short stories use in EFL classrooms published in 2011 and 2020. Due to the short time limit, only 12 articles were selected. Consequently, more are action research is needed to provide more comprehensive information on how to use action short stories to help students achieve better results in various EFL learning areas. Moreover, as the research gaps section reveals, future action research is also recommended to involve young learners and elementary school students.

\section{LIMITATION}

This review was conducted only by one researcher. So, although it established four inclusion and three exclusion criteria to minimize subjectivity, the level of subjectivity might be high. Future reviewers are, therefore, invited to examine the studies to ensure reliability.

\section{BIO-PROFILE}

Parlindungan Pardede earned his bachelor's degree in English Language and Literature from Universitas Padjadjaran Bandung and his master's degree in applied Linguistics from Universitas Negeri Jakarta. His research interest includes ICT in language learning and teaching, language skills, and literature use in ELT. Corresponding email: parlpard2010@gmail.com 


\section{REFERENCES}

Ahmed, N. (2017). Vocabulary Enhancement of Female ESL Learners through Short Stories: A Rural/ Urban Perspective. Language and Language Teaching Journal, 20(2), 113118.

Ali, A. D. (2020). Implementing Action Research in EFL/ESL Classrooms: A Systematic Review of Literature 2010-2019. Systemic Practice and Action Research, 33(3), 341362.

Bartan, Ö. Sen. (2017). The Effects of Reading Short Stories in Improving Foreign Language Writing Skills. The Reading Matrix, 17(1), 59-74.

Burns, A. (1999). Collaborative action research for English language teachers. Cambridge University Press.

COBE. (2005). Action Research: A Guide for Associate Lecturers. In The Open University. Open University.

Cohen, L., Manion, L., \& Morrison, K. (2007). Research methods in education (7th ed.). Routledge.

Collie, J., \& Slater, S. (1991). Literature in the language classroom. Cambridge University Press.

Crane, P., \& Rihardson, L. (2000). Action Research Induction Kit. Commonwealth of Australia.

Dania, R. (2020). Using Online Short Stories to Promote Students' Reading Habit. Advances in Social Science, Education and Humanities Research, 411(Icoelt 2019), 140-144. https://doi.org/10.2991/assehr.k.200306.025

Ferrance, E. (2000). Themes in education: Action research. Northeast and Islands Regional Educational Laboratory.

Ganakumaran, S., Shahizah, I. H., \& Koo, Y. L. (2003). Pedagogical implications of the incorporation of the Literature Component in the Malaysian ESL syllabus. In The Malaysian ESL syllabus in teaching of literature in ESL/EFL contexts. (pp. 62-87). Sasbadi.

Ghazanfari, M., Ziaee, M., \& Sharifianfar, E. (2014). The Impact of Illustrations on Recall of Short Stories. Procedia - Social and Behavioral Sciences, 98, 572-579. https://doi.org/10.1016/j.sbspro.2014.03.453

Ghosn, I. K. (2002). Four good reasons to use literature in primary school ELT. ELT Journal, 56(2), 172-179. https://doi.org/https://doi.org/10.1093/elt/56.2.172

Guritno, A. (2017). Short stories: the powerful media to foster students' vocabulary mastery in reading. IDEAS (Journal on English Language Teaching \& Learning, Linguistics \& Literature), Vol 5.

Gusenbauer, M. (2019). Google Scholar to overshadow them all? Comparing the sizes of 12 
academic search engines and bibliographic databases. In Scientometrics (Vol. 118, Issue 1). Springer International Publishing. https://doi.org/10.1007/s11192-018-2958-5

Hall, G. (2005). Literature in language education. Palgrave MacMillan.

Handayani, M. P. (2013). Using Children Short Stories To Enhance Students' Reading Comprehension. Journal of English and Education, 1(1), 133-141.

Hişmanoğlu, M. (2005). Journal of Language and Linguistic Studies Vol.1, No.1, April 2005 Teaching English Through Literature. English, 1(1), 53-66.

Iman, J. N. (2017). A Quasi-Experimental Study on Using Short Stories: Statistical and Inferential Analyses on the Non-English Major University Students' Speaking and Writing Achievements. International Journal of Languages' Education, 1(Volume 5 Issue 1), 421-433. https://doi.org/10.18298/ijlet.1719

Ismail, I., Samad, I. S., \& Masnur. (2019). The impact of interactive reading using local folktales stories in supporting students 'vocabulary achievement in Indonesian EFL learners. Majesty Journal, 1(2), 25-37. https://doi.org/https://doi.org/10.33487/majesty.v1i2.119

Khatib, M., \& Mehrgan, K. (2012). Achieving Critical Thinking Skills through Reading Short Stories 1. Advances in Digital Multimedia, 1(3), 140-145.

Khatib, M., \& Nourzadeh, S. (2011). Some Recommendations for Integrating Literature into EFL/ESL Classrooms. International Journal of English Linguistics, 1(2), 258-263. https://doi.org/10.5539/ijel.v1n2p258

King, I. (2001). Beyond Cinderella: Using stories with secondary and adult learners. BETAIATEFL: Language and Linguistic Studies, 4(2), 94-106.

Kitchenham, B., \& Charters, S. (2007). Guidelines for performing systematic literature reviews in software engineering. In EBSE Technical Report.

Kramsch, C., \& Kramsch, O. (2002). The Avatars of Literature in Language Study. The Modern Language Study, 84, 553-573. https://doi.org/https://doi.org/10.1111/00267902.00087

Laadi, W. A., Ohoiwutun, J. E., \& Hastini. (2014). the Use of Short Story in Teaching Pronunciation of English Vowel Sounds. E-Journal of English Language Teaching Society (ELTS), 2(2), 1-15.

Lazar, G. (1993). Literature and language teaching. Cambridge University Press.

Lima, C. (2010). Selecting Literary Texts for Language Learning. Journal of NELTA, 15(12), 110-113. https://doi.org/10.3126/nelta.v15i1-2.4616

Littell, J. H., Jacqueline, C., \& Pillay, V. (2008). Systematic reviews and meta-analysis. Oxford University Press.

Mantra, I. B. N. (2017). Promoting the students ' writing skill through folktales based learning activities. International Seminar on Language, Education, and Culture, July, 78-82.

Mantra, I. B. N., \& Kumara, D. G. A. G. (2018). Folktales As Meaningful Cultural and Linguistic Resources To Improve Students’ Reading Skills. Lingua Scientia, 25(2), 83.

Premise Journal Volume 10 No 2, October 2021, e-ISSN: 2442-482x, p-ISSN: 2089-3345, page 165-182 Copyright@2021 
https://doi.org/10.23887/ls.v25i2.18827

Mills, G. E. (2007). Action research: A guide for the teacher researcher. Pearson Education, Inc.

Mourao, S. (2009). Using Stories in the Primary Classroom. In BritLit: Using Literature in EFL Classrooms (pp. 17-26). The British Council.

Murdoch, G. (2002). Exploiting Well Known Short Stories for Language Skills Development. IATEFL LCS SIG Newsletter, 23, 9-17.

Nasirahmadi, A., Madarsara, F. A., \& Aghdam, H. R. (2014). Cultural Issues and Teaching Literature for Language Learning. Procedia - Social and Behavioral Sciences, 98, 13251330. https://doi.org/10.1016/j.sbspro.2014.03.549

Omidi, M., \& Zafarghandi, A. M. (2016). The Effect of Short-story Retelling on Iranian Intermediate EFL Learners' Speaking Skill. Journal of Applied Linguistics and Language Research, 3(4), 234-252.

Pardede, P. (2021). A Review of Current Conceptual Research on Short Stories Use in EFL Classrooms. JET (Journal of English Teaching), 7(1), 31-42. https://doi.org/10.33541/jet.v7i1.2595

Pardede, P. (2019). Seeing Action Research Process in a Practice. In P. Pardede (Ed.), EED Collegiate Forum 2015-2018 (Issue October, pp. 282-295). UKI Press.

Parkinson, B., \& Reid-Thomas, H. (2000). Teaching literature in a second language. Oxford University press.

Pathan, M. M. (2013). The Use of Short Stories in EFL Classroom: Advantages and Implications. Labyrinth: An International Refereed Journal of Postmodern Studies, 4(2), 21-26.

Pradana, S. A. (2015). The Effect of English Short Story Reading Habit on Students' Ability in Writing Narrative Text. English Education: Jurnal Tadris Bahasa Inggris, 8(1), 1738. https://doi.org/https://doi.org/10.24042/ee-jtbi.v8i1.507

Saka, F. Ö. (2014). Short stories in English language teaching. 1(4), 278-288.

Sarifah, W., \& Suhartini, S. (2019). Improving Students Motivation through Short Story in Learning English. Jurnal Al-Ta'dib, 10(2), 109-126.

Savvidow, C. (2004). An Integrated Approach to Teaching Literature in the EFL Classroom (TESL/TEFL). The Internet TESL Journal, 10(2).

Şentürk, S., \& Kahraman, A. (2017). The use of short stories in English language teaching and its benefits on grammar learning conditions of the Creative Commons Attribution license (CC BY-NC-ND). International Journal of Curriculum and Instruction, 12(2), $533-559$.

Tamjid, N. H., \& Hassanzadeh, L. (2012). The Effect of Digital Stories on Enhancing Iranian Pre-intermediate EFL Learners' Listening Comprehension. Journal of Applied Linguistics, 5(11), 29-44.

Turmudi, D. (2020). English Scholarly Publishing Activities in the Industrial Revolution 4 .

Premise Joumal Volume 10 No 2, October 2021, e-ISSN: 2442-482x, p-ISSN: 2089-3345, page 165-182 Copyright@2021 
0 : What, Why, and How ? ELTEJ, 3(1), 52-62.

http://journal2.uad.ac.id/index.php/eltej/article/view/1890

Vaughan, M., \& Burnaford, G. (2016). Action research in graduate teacher education: a review of the literature 2000-2015. Educational Action Research, 24(2), 280-299. https://doi.org/10.1080/09650792.2015.1062408

Vural, H. (2013). Use of Literature to Enhance Motivation in ELT Classes. Mevlana International Journal of Education, 3(4), 15-23. https://doi.org/10.13054/mije.13.44.3.4 